\title{
Liquidation of consequences of oil spills
}

\author{
V. I. Reshnyak ${ }^{1}$, K. A. Kazmin ${ }^{1, *}$ \\ ${ }^{1}$ Admiral Makarov State University of Maritime and Inland Shipping, St. Petersburg, Russian \\ Federation
}

\begin{abstract}
The paper is devoted to the organization of cleaning oily water, which is one of the parties to the problem of environmental protection in case of accidental oil spills. The oily water is formed during the elimination of an accidental spill. The organization of oily water purification is a limiting factor determining the effectiveness of the entire accidental spill response operation. Firstly, the organization of oily water purification is characterized by the effectiveness of the purification devices used. Secondly, it is characterized by the organization itself providing the response to an emergency spill with these devices. It has been stated that the effectiveness of cleaning devices is determined by the technology used in the cleaning device and by its design. Purification technology is determined by the properties of the treated oily water and the purification quality requirements. The technical solution for a cleaning device that can be applied for oil spill response has been proposed. The organizational and layout schemes for providing an oil spill response were developed, which makes it possible to select the most proper scheme considering the conditions for particular spill response.
\end{abstract}

\section{Introduction}

Water transport facilities are sources of environmental pollution like other technological objects [1-4]. As is known, the process of environmental pollution can proceed in different ways, having different causes and consequences [5-6]. Therefore, the contributors of those papers propose to distinguish two such types of pollution, as operational and accidental. The first indicates the proper operation process of man-made objects. The second indicates an emergency situation.

One of the most relevant examples of accidental pollution at water transport facilities is the emergency spill of oil or petroleum products that may occur during their delivery to consumers. Taking into account the experience of using water transport for these purposes, the delivering process of oil or petroleum products is characterized by a high level of environmental hazard [7-10].

At this point, technical means for elimination of accidental oil spills have been created and are being used [11]. This technical means include two main groups. The first group includes means for localizing the spill spot. The second group includes means for the elimination of spill spots, which means removal from water surface and the coastline. In turn, each of these groups includes devices that have different design and operation

${ }^{*}$ Corresponding author: rv53@mail.ru 
principle, and, therefore, can be applied in different situations [12]. However, removing the oil isn't the complete solution to the problem of environmental protection. That is due to the fact that as a result of the elimination of oil stains, a mixture of water and oil is formed, which cannot be considered a marketable product, as well as it can't be dumped into a reservoir. A mixture of water and oil can be of two main types. It can be either flooded oil, which is a mixture where the water content can vary from full percentage points to fractions of percent. Otherwise, it can be oily water, in which the amount of oil can also vary from full percentage points to fractions of percent. In any case, such mixture requires processing. In the first case, such processing should ensure the removal of water from the mixture, and in the second case it should ensure the purification of oily water from petroleum products. This paper is devoted to solving the problem of cleaning oily water. Solving that problem requires the development of the basis for processing technology, the creation of technical means to ensure such processing.

However, the problem of cleaning oily water in the case when it is formed during the accidental oil spill response, is also characterized by the organization of oily water purification. The main determining factors of the treatment organization are the amount of formed oily water and the location of the oil spill. Usually, this amount is significant, and the spill site is quite remote from the treatment plant. In such cases, the circumstances become the limiting factor for the effective response to the spill as a whole. Therefore, the effective response to a spill requires the development of organizational schemes that can be applied in different situations.

\section{Methods and materials}

The main theoretical prerequisites that have been put as a foundation for the development of processing technology as a combination of some processes are the understanding that this technology is determined by the properties of the treated oily water, as well as the requirements for the quality of purified water. Another underlying theory of the solution to the purifying oily water problem is the following. The quality of water purification is determined not only by the purification technology, but also by the design characteristics of the cleaning devices. Purification technology, which is a combination and sequence of some processes, is implemented in purification devices. Practice shows that sometimes, even with a properly chosen purification technology implemented in cleaning devices, the expected quality is not always ensured [13]. The reason is the design characteristics of the cleaning devices.

The influence of the purified water properties on the purification technology was determined by academician L.A. Kulsky [14]. In his researches, the main principle of organizing the water purification is that each state, in which pollutants may present, corresponds to certain cleaning methods. This yields the following principle, if the polluted water usually is a complex dispersed-phase system, then several operations will be necessary to remove contaminants. This is called a cleaning technology. Therefore, the development of water treatment technology, including oil-containing water, should be based on the analysis of the polluted water properties.

\section{Results and discussion}

The oily water, formed during the elimination of the spill spot, is a dispersed-phase system, in which water is a dispersed medium, and oil products is a dispersed phase. Such methods as sedimentation, adsorption, cleaning in the centrifugal field, flotation can be used to purify water from oil products in such state. The final choice and development of cleaning 
devices, in which the selected cleaning processes will take place, should take into account the conditions of their use and the specifics of the spill response organization. The simplest for instrumentation and service support are sedimentation and adsorption. Therefore, these methods are widely used in cases when there is a need to purify water containing petroleum products [13].

For example, a device that is presented in fig. 1 can be used.

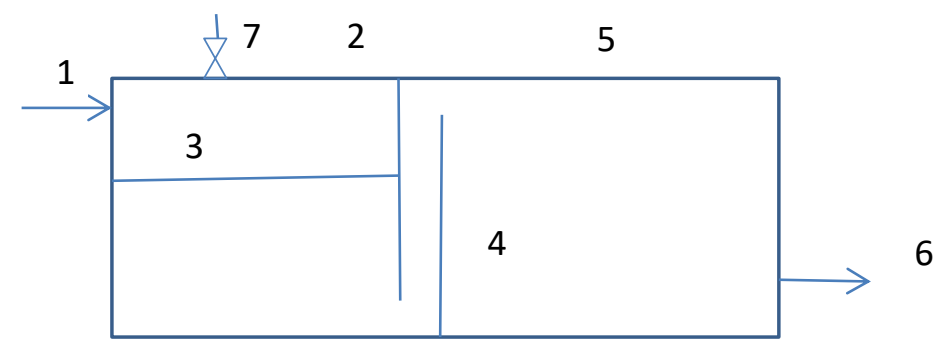

Fig. 1. Purifying device for oil-consisting water: 1 - supply of treated water; 2 -adsorption compartment; 3 - adsorption layer; 4 - bypass channel; 5 - sedimentation compartment; 6 - release of purified water; 7 - release of petroleum products.

The device consists of two main parts, the adsorption compartment 2 and sedimentation compartment 5. Same oil products that are contained in the treated water are used as the absorption layer 3 . The purified water is supplied to the inlet pipe 1, then it moves through the adsorption layer, which absorbs the petroleum products contained in the purified water. The petroleum products accumulated in the adsorption layer are periodically removed via the valve 7 . Through the bypass channel 4 , the treated water enters the sedimentation compartment 5 , in which its final purification from oil products takes place. Such a device can be used in any of the following organizational and layout schemes for the purification of the oily water.

If necessary, this construction can be equipped with a group of adsorption filters [15]. Ozonation may be proposed as an additional purification for stationary floating or coastal treatment facilities [16]. Case history with these cleaning methods shows the feasibility of their use.

As mentioned above, another side of the shield of oil spill response is the organizational aspect. The main reason for this is the correlation between the effectiveness of spill response and the remoteness of the spill site from the location of the technical means for spill response, including treatment facilities. The effectiveness of spill response largely depends on the delivery speed of these technical means to the spill site.

Considering the peculiarities of oily water formation, the following organizational and layout schemes can be applied for its purification (Fig. 2).

a)

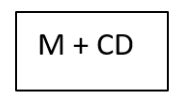

b)

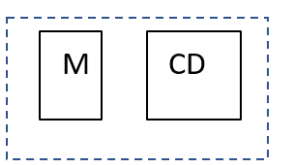

c)

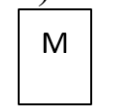

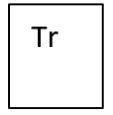

d)

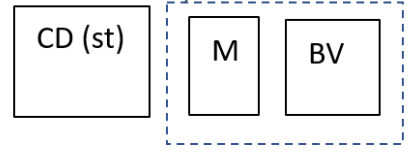

$\mathrm{CD}$

(m)

Fig. 2. Organizational and layout schemes for oily water purification during oil spill response.

Option (a) for arranging the technical means in order to eliminate the spill stain (M) and the cleaning device (CD) is a construction, which structurally combines these two devices. Such a construction provides the immediate removal of the spill stain and the purification of oily water formed during the removal of the oil stain. 
The next option (b) involves the use of structurally different devices for the elimination of the spill stain and the purification of oily water. In this case the devices and oil stains are in close proximity to each other in the area of the oil spill response. For example, the cleaning device 1 as an independent structure can be located right behind the booms 2 (Fig. 3 ) localizing the spill spot 3 . The resulting purified water is supplied from the device 4 to the cleaning device through pipeline 5 in order to eliminate the spill spot. Another application of scheme (b) is the use of stationary (coastal or floating) treatment facilities located near the port or berths of the oil terminal.

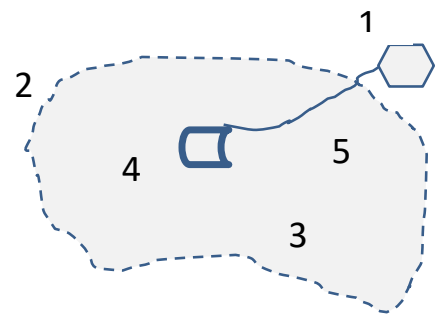

Fig. 3. Application options for purification devices: 1 - cleaning device; 2 - booms; 3 - spill stain; 4 - a device for the elimination of oil stains; 5 - pipeline.

Another option for the implementation of this organizational and layout scheme can be the placement of a cleaning device on board of the service vessel, which delivers and sets up booms. It also delivers and operates the devices for the spill stain elimination.

One more option (c) involves the remote location of stationary oily water cleaning devices CD (st) from the place of the oil spill, which requires organizing the transportation of the resulting oily water to the treatment plant. This option is the most unfavorable, however, it can also be considered due to some objective circumstances.

Option (d) involves the use of buffer vessels (BV) for the temporary storage of the resulting oily water. Buffer vessels are located directly at the spill spot elimination site. Subsequent purification of oily water can be provided during its transportation to remote treatment plants or at the spill site using a mobile treatment plant. It can have, for example, the form of a vessel (even high speed one) equipped with a treatment device. At the moment, floating vessels made of plastic material are already being produced and used. Such containers are compact in the stowed position and convenient for delivery. In addition, the containers can be used not only as storage, but also as transport to move the oily water to the place of its purification.

For stationary objects, which are potentially dangerous in terms of possible oil spills, the most appropriate options are (b) and (d).

\section{Discussion}

The main steps of an emergency spill response have been established according to a systematic analysis of the environmental protection problem in case of an oil spill. This is essential in the process of organizing the emergency oil spill response, since the study of this problem focuses the attention of researchers and specialists only on the operation of eliminating the oil spill spot [8], [17]. At the same time, according to the contributors, the limiting factor is not only the effective organization of the operation to eliminate the oil spill, but also the organization of the oily water purification, which is formed during the process of eliminating the spill stain. Analyzing the experience of purifying oily water shows that devices for oily water purification not always provide the required quality [13]. 
The factors that determine the efficiency of cleaning the oily water were analyzed and the basic principles were formulated. Following these principles allow to create effective cleaning devices. These principles are based on the theoretical foundations of water purification technology developed by academician L.A. Kulsky [14]. Another prerequisite for an effective oil spill response is the organization of the oily water purification. Several options of such organization were proposed. They are distinguished by a set of technical means that can be used for this process.

\section{Conclusions}

Thus, the main steps of spill response were developed. The steps include stopping the oil flow into the environment in the case of an accidental spill, the actual elimination of the spill and the elimination of the consequences. It is shown that the operation of the spill response is limiting in the general process of spill response. The main factors determining the efficiency of oil spill response have been determined. These factors include design and engineering, as well as organizational ones. The design and engineering factor includes the theoretical basis of creating effective purifying means for oily water. A construction of a device, which provides such cleaning was proposed. The organizational factor reflects the role of organizing the purification of oily water, which appears after the elimination of the spill stain. Several organizational and layout schemes for the purification of oily water have been proposed.

\section{References}

1. A.K. Brodskii, Ekologiia vodnogo transporta (Akademiia, M., 2006)

2. V.I. Reshnyak, Okhrana okruzhaiushchei sredy na vodnom transporte (Izd-vo SPbGUVK, SPb, 2010)

3. V.I. Reshnyak, S.S. Sokolov, A.P. Nyrkov, V.A. Budnik, International Conference Information Technologies in Business and Industry 2018, IOP Conf. Series: Journal of Physics: Conf. Series 1015 (2018)

4. S.P. Zubrilov, Iu.G. Ishchuk, V.I. Kosovskii, Okhrana okruzhaiushchei sredy pri ekspluatatsii sudov (Sudostroenie, L., 1989)

5. V.I. Reshnyak, Sistema upravleniia ekologicheskoi bezopasnostiu pri ekspluatatsii sudov na vnutrennikh vodnykh putiakh, monografiia (Izd-vo GUMRF im. adm. S.O. Makarova, SPb, 2017)

6. V.I. Reshnyak, Z. Iuzviak, A.G. Shchurov, Zhurnal universiteta vodnykh kommunikatsii 17, 85-90 (2013)

7. V.L. Etin, E.Iu. Cheban, V.M. Ivanov, S.V. Vaskin, E.A. Lukina, F.S. Sosenkov, Organizatsiia borby s razlivami nefti na vnutrennikh vodnykh putiakh (Izdatelstvo FGBOU VO «VGUVT», Nizhnii Novgorod, 2015)

8. A.I. Alkhimenko, Avariinye razlivy nefti v more i borba s nimi (OMPress, SPb, 2005)

9. V.S. Naumov, Predotvrashchenie zagriazneniia okruzhaiushchei sredy na vnutrennem vodnom transporte upravleniem antropogennoi nagruzkoi, diss. doktora tekhn. nauk (Nizhnii Novgorod, 2003)

10. A.E. Plastinin, Nauchnye osnovy prognozirovaniia $m$ analiza ekologicheskikh posledstvii razlivov nefti na vnutrennikh vodnykh putiakh, dis. doktora. tekhn. Nauk (Nizhn. Novgorod, 2016) 
11. V.I. Reshnyak, Vestnik Gosudarstvennogo universiteta morskogo i rechnogo flota imeni admirala S. O. Makarova 10(2) (2018)

12. V.I. Reshnyak, Ekologicheskaia bezopasnost pri peregruzke nefti i nefteproduktov $v$ portakh (SPbGUVK, SPb, 2007)

13. V.I. Reshnyak, Predotvrashchenie zagriazneniia vodoemov neftesoderzhashchei podslanevoi vodoi pri ekspluatatsii sudov $i$ sudovykh energeticheskikh ustanovok (SPbGUVK, SPb, 2011)

14. L.A. Kulskii, Osnovy khimii i tekhnologii vody (Naukova dumka, Kiev, 1991)

15. V.I. Reshnyak, A.I. Kaliaush, Vestnik GUMRF im. adm. S. O. Makarova 2(30), 57-60 (2015)

16. V.I. Reshnyak, A.I. Kaliaush, K.V. Reshnyak, Vestnik GUMRF im. adm. S. O. Makarova 5(27), 135-140 (2014)

17. Rukovodstvo likvidatsii razlivov nefti na moriakh, ozerakh i rekakh (Morsar, SPb, 2002) 